\title{
HUBUNGAN ANTARA EFEKTIVITAS KEPEMIMPINAN KEPALA SEKOLAH DAN IKLIM ORGANISASI DENGAN PRODUKTIVITAS KERJA GURU SEKOLAH DASAR NEGERI DI KECAMATAN TENGGARONG
}

\author{
M. Azhari \\ Universitas Kutai Kartanegara \\ azhari76@yahoo.co.id
}

\begin{abstract}
Abstrak
Penelitian ini bertujuan untuk mengetahui hubungan antara efektivitas kepemimpinan kepala sekolah dengan produktivitas kerja guru, hubungan antara iklim organisasi dengan produktivitas kerja guru, hubungan antara efektivitas kepemimpinan kepala sekolah dan iklim organisasi secara bersama-sama dengan produktivitas kerja guru. Populasi penelitian adalah guru-guru SDN di Kecamatan Tenggarong sebanyak 750 orang. Sampel penelitian sejumlah 88 orang yang diambil secara acak (Proporsional Random Sampling). Metode penelitian ini adalah kuantitatif jenis deskriptif studi korelasional. Hasil analisis diskriptif mengungkapkan bahwa produktivitas kerja guru mayoritas pada kategori sedang yaitu sebesar $70 \%$, efektivitas kepemimpinan kepala sekolah mayoritas pada kategori sedang yaitu sebesar $73 \%$, dan pada iklim organisasi mayoritas pada kategori sedang yaitu sebesar $70 \%$. Sehingga dengan demikian secara diskriptif baik produktivitas kerja guru, efektivitas kepemimpinan kepala sekolah dan iklim organisasi pada kategori sedang. Hasil analisis inferensial menemukan bahwa (a) terdapat hubungan yang positif dan signifikan variabel efektivitas kepemimpinan kepala sekolah $\left(\mathrm{X}_{1}\right)$ dengan variabel produktivitas kerja guru SDN di Kecamatan Tenggarong (Y) pada tingkat keeratan yang lemah, yaitu sebesar 0,356 dengan nilai koefisien determinasi 0,114 , dan persamaan regresi $\hat{Y}=37,438+0,56 \mathrm{X}_{1}$ (b) terdapat hubungan yang positif dan signifikan variabel iklim organisasi $\left(\mathrm{X}_{2}\right)$ dengan variabel produktivitas kerja (Y) pada tingkat keeratan yang sedang, yaitu sebesar 0,491 dengan nilai koefisien determinasi 0,2411, dan persamaan regresi $\hat{Y}=9,082+1.199 \mathrm{X}_{2}(\mathrm{c})$ terdapat hubungan yang positif dan sangat signifikan antara variabel efektivitas kepemimpinan kepala sekolah $\left(\mathrm{X}_{1}\right)$ dan variabel iklim organisasi $\left(\mathrm{X}_{2}\right)$ secara bersama-sama dengan variabel produktivitas kerja guru SDN di Kecamatan Tenggarong (Y) pada tingkat keeratan yang sedang, yaitu sebesar 0,646 dengan nilai koefisien determinasi 0,418 dan persamaan regresi $\hat{\mathrm{Y}}=11.460+0.152 \mathrm{X}_{1}+1.317 \mathrm{X}_{2}$
\end{abstract}

Kata Kunci: efektivitas, iklim organisasi, produktivitas

\section{Abstract}

The research purposes are to find out the relationship between effectiveness principals leadership with teachers work productivity, the relationship between organisational climate with teachers work productivity, the relationship between effectiveness principals leadership and organisational climate simultaneously with teacher's work productivity. The population of this research were teachers of elementary school in Tenggarong District, with the total of 750 teachers and 88 of them were taken as sample by using random sampling. Quantitative research method is the kind of descriptive research with correlative study. The result of descriptive analysis showed that there has constribution teachers work productivity was in middle category, is equal to $60 \%$, the majority of effectiveness principals leadership in middle category that is equal to 56\%, and the organisational climate is in the middle category. So majority that is equal to $62 \%$. Thus a good descriptive performance, motivation and discipline of teachers working at the medium category. The results found that (a) there was a positive and significant relationship between effectiveness principals leadership (X1) with teacher's work productivity (Y) at a weak level, amounting to 0.356 with a 0.114 coefficient of determination, and the regression equation $\hat{Y}=$ $37.438+0.56 X 1$. (b) there was a positive and significant relationship of organizational climate (X2) teacher's work productivity $(Y)$ at the current level of closeness, amounting to 0.491 with a coefficient of determination value of 0.2411 , and the regression equation $Y=9.082+1199 X 2$ (c) there was a positive and highly significant correlation between the variables of work motivation of teachers (XI) and the variable of work discipline teachers (X2) together with special-ed teacher performance variables 
Samarinda (Y) at the level of closeness that is, that is equal to 0.646 with value coefficient of determination of 0.418 and regression equation $y=11460+0.152 X 1+1.317 X 2$.

Keywords: effectiveness, organisational climate, productivity

\section{PENDAHULUAN}

Sejak pendiri Negara Republik Indonesia sepakat untuk mendirikan sebuah negara yang merdeka, pendidikan menduduki posisi penting yang menjadi prioritas pembangunan negara ini. Dengan dimasukkan kalimat "dengan mencerdaskan kehidupan bangsa" dipembukaan Undang-Undang Dasar 1945 merupakan bukti keseriusan para pendiri negara ini dalam meningkatkan sumber daya manusia Indonesia yang mempunyai harkat dan martabat yang tinggi. Berbagai upaya telah dilakukan untuk meningkatkan mutu pendidikan di Indonesia baik konsep maupun kebijakan yang mengarah pada pencapaian penyempurnaan sistem pendidikan. Dalam kerangka sistem otonomi daerah khususnya di Kecamatan Tenggarong profesionalime tenaga pendidik menjadi penting peranannya dalam mengatur dan menampung aspirasi masyarakat sekitar, karena secara otonomi lembaga pendidikan diberikan wewenang untuk bersama-sama mendorong peningkatan kualitas pendidikan. termasuk di dalamnya pengembangan tenaga kependidikan, kepala sekolah dan guru.

Hal ini sesuai dengan tuntutan undang-undang tentang Sistem pendidikan Nasional nomor 20 tahun 2003 pasal 41 (3), bahwa pemerintah dan pemerintah daerah wajib memfasilitasi satuan pendidikan dan pendidik dan tenaga pendidik yang diperlukan untuk menjamin terse! enggaranya pendidikan yang bermutu.

.Dalam pasal 39 (1) disebutkan bahwa tenaga kependidikan bertugas melaksanakan administrasi, pengelolaan, pengembangan, pengawasan dan pelayanan teknis untuk menunjang proses pendidikan pada satuan pendidikan. Sekolah sebagai lembaga pendidikan formal terdiri dari berbagai unsur. Manusia merupakan unsur yang paling penting dalam organisasi sekolah tersebut. Personil intern sekolah terdiri dari kepala sekolah, guru, pegawai tata usaha, dan siswa, serta pegawai lainnya, seluruhnya bekerja sama untuk mencapai tujuan yang telah ditetapkan. Tujuan utamanya ialah meningkatkan produktifitas organisasi sekolah. Untuk rnencapai tujuan organisasi sekolah tersebut diperlukan kerja sama seluruh personil yang ditunjang oleh sarana dan prasarana yang cukup memadai. Agar kerja sama itu efektif diperlukan kepemimpinan yang efektif pula. Dengan demikian dalam kepemimpinan kepala sekolah tersebut perlu kepemimpinan yang dapat melakukan kontrol dan evaluasi terhadap guru dan personil lainnya di sekolah. Karena dalam prakteknya kepala sekolah harus bertanggung jawab terhadap seluruh kegiatan di sekolah, sehingga kepemimpinan yang efektif akan mewarnai sekolah yang ia pimpin.

Sesuai dengan pendapat tersebut, bahwa kepala sekolah memiliki peranan yang sangat penting, karena maju mundurnya suatu sekolah tergantung bagaimana kepala sekolah tersebut. Dalam melakukan peranannya efektivitas kepemimpinan kepala sekolah berpengaruh pada produktivitas kerja guru dalam sekolah tersebut.

Dalam uraian Permendiknas Nomor 13 Tahun 2007 tentang Standar Kompetensi Kepala Sekolah (2007: 102) dijelaskan bahwa 'kepala sekolah yang berkinerja baik diperlihatkan dalam kemampuan manajemen kepala sekolah yang mampu: (a) menjabarkan sumber daya yang adauntuk menyediakan dukungan yang memadai bagi guru, bahan pelajaran danpemeliharaan fasilitas yang baik; (b) memberikan waktu yang cukup untuk pengelolaan dan koordinasi proses belajar mengajar; (c) berkomunikasi secara teratur dengan staf, orang tua siswa, siswa dan masyarakat terkait'.

Dengan kata lain, bahwa produktivitas sekolah ditentukan oleh efektivitas kepemimpinan kepala sekolah.. Keberhasilan kepala sekolah dalam mengelola organisasi sekolah ditentukan oleh kepemimpinan kepala sekolah yang efektif pula. Apabila kepala sekolah mampu menggerakkan,membimbing, dan mengarahkan anggota secara tepat, segala kegiatan yang ada dalam organisasi sekolah akan bisa terlaksana secara efektif. Sebaliknya, bila tidak bisa menggerakkan anggota secara efektif, tidak akan bisa mencapai tujuan secara optimal

Pengangkatan kepala sekolah SDN di Kecamatan Tenggarong tidak didasarkan penilaian yang obyektif dan kriteria kepala sekola, seperti tertuang dalam Permendiknas Nomor 13 Tahun 2007, tetapi hanya didasarkan 
karena masa kerjanya sudah lama dan golongannya sudah tinggi.

- Indikator lain yang mendukung produktivitas kerja adalah iklim organisasi yang kondusif. Semakin kondusif iklim sebuah organisasi, maka produktivitas kerja anggotanya akan meningkat. Produktivitas kerja yang tinggi menandakan bahwa sebuah organisasi sekolah telah dikelola dengan baik dengan manajemen yang efektif.. Meningkatkan produktivitas kerja bagi guru merupakan hal yang sangat penting, karena menyangkut masalah hasil kerja guru yang merupakan salah satu langkah dalam

\section{METODE}

Penelitian ini akan menggunakan metode survey dengan pendekatan korelasional, yaitu menghubungkan antara satu variabel dengan variabel lainnya. Korelasi ini untuk memahami suatu fenomena dengan cara menentukan tingkat atau derajat pengaruh diantara variabel-variabel tersebut. Dengan melalui analisis korelasional ini akan dapat diungkapkan keterkaitan antara

\section{HASIL DAN PEMBAHASAN}

Pengujian hipotesis penelitian dilakukan setelah uji persyaratan analisis regresi telah terpenuhi. Regresi dilakukan untuk menguji hubungan antara variabel, selain itu pula untuk mengetahui seberapa besar korelasi variabel bebas $\mathrm{X}_{1}$ dan $\mathrm{X}_{2}$ dengan variabel $\mathrm{Y}$. Pengujian hipotesis dalam hal ini adalah untuk menguji hubungan antara variabel bebas secara sendiri-sendiri yang terdiri atas efektivitas kepemimpinan kepala sekolah dan iklim organisasi dengan variabel terikat yaitu produktivitas kerja guru SD Negeri di Kecamatan Tenggarong dan menguji hubungan variabel bebas tersebut secara bersama-sama dengan variabel terikat.

Landasan teoritis yang digunakan untuk pengajuan hipotesis dalam penelitian ini menggunakan kaidah induktif yang berarti mengambil hipotesis secara khusus, yaitu hubungan masing-masing variabel terikat. Setelah hubungan masing-masing variabel bebas dengan variabel terikat diketahui, maka dilanjutkan dengan melihat hubungan kedua variabel bebas secara bersama-sama terhadap variabel terikat. Agar dapat menjawab hipotesis yang diajukan maka dilakukan pengujian koofisien determinasi terstandar Beta yang dilanjutkan pengujian regresi linier ganda. meningkatkan mutu pelayanan kepada stakeholder pendidikan

Adanya fenomena menurunnya semangat mengajar, kerja yang menjenuhkan, suasana lingkungan kerja yang tidak kondusif, rekan kerja yang tidak saling mendukung, pimpinan yang kurang bijak serta siswa yang tingkah lakunya menjengkelkan adalah faktor yang sering menjadi keluhan guru sekolah dasar negeri di Kecamatan Tenggarong.

variabel-variabel efektivitas kepemimpinan kepala sekolah dan iklim organisasi dengan variabel produktivitas kerja. Ada tiga variabel dalam penelitian ini, yaitu variabel bebas yang berkaitan dengan efektivitas kepemimpinan kepala sekolah dan iklim organisasi serta variabel terikat yang berkaitan dengan produktivitas kerja.

Untuk mengetahui korelasi atau hubungan antara variabel penelitian tersebut digunakan teknik statistik korelasi Product Moment. Besarnya kontribusi variabel bebas (X1 dan X2) terhadap variabel terikat (Y) digunakan teknik analisis regresi ganda dengan memanfaatkan program SPSS for windows versi 16.0 .

\section{Hubungan antara Efektivitas Kepemimpinan Kepala Sekolah $\left(\mathrm{X}_{1}\right)$ dengan Produktivitas Kerja Guru (Y)}

Hipotesis yang diuji adalah:

$\mathrm{H}_{\mathrm{o}}: \rho_{\mathrm{y} 1}=0$

$\mathrm{H}_{1}: \rho_{\mathrm{y} 1}>0$

Hipotesis yang dikemukakan untuk hipotesis alternatif $\left(\mathrm{H}_{1}\right)$ adalah "terdapat hubungan yang positif dan signifikan antara efektivitas kepemimpinan kepala sekolah dengan produktivitas kerja guru SD Negeri di Kecamatan Tenggarong". Sedangkan untuk hipotesis nol $\left(\mathrm{H}_{0}\right)$ dirumuskan, "tidak terdapat hubungan yang positif dan signifikan antara efektivitas kepemimpinan kepala sekolah dengan produktivitas kerja guru SD Negeri di Kecamatan Tenggarong”. Untuk keperluan pengujian digunakan analisis regresi sederhana dan korelasi sederhana. 
Hasil perhitungan analisis regresi uji signifikansi persamaan garis regresi sederhana dan linieritas antara variabel efektivitas kepemimpinan kepala sekolah $\left(\mathrm{X}_{1}\right)$ dengan produktivitas kerja guru (Y) menghasilkan arah regresi (b) sebesar 0,608 dan konstanta (a) sebesar 34,222. Dengan demikian bentuk hubungan antara kedua variabel tersebut dapat digambarkan oleh persamaan $\hat{Y}=34,222$. + $0,608 \mathrm{X}_{1}$.

Selanjutnya untuk mengetahui derajat keberartian persamaan regresi dilakukan dengan uji F. Persyaratan hipotesis apabila Sig $<\alpha=$ 0,05 . Berdasarkan hasil perhitungan uji signifikansi regresi seperti tampak pada tabel 21 diperoleh nilai $\mathrm{Sig}=0,000$. Apabila nilai sig di bandingkan dengan nilai $\alpha$, maka $0,000<0,05$. Hal ini menunjukan bahwa hubungan antara variabel efektivitas kepemimpinan kepala sekolah $\left(\mathrm{X}_{1}\right)$ dengan variabel produktivitas kerja guru (Y) adalah positif dan signifikan. Selengkapnya hasil perhitungan uji signifikansi dan nilai koefisien regreasi antara variabel efektivitas kepemimpinan kepala sekolah $\left(\mathrm{X}_{1}\right)$ dengan variabel produktivitas kerja guru (Y) dapat dilihat pada tabel di bawah ini

Tabel 21

Analisis Varians Uji Signifikansi Persamaan Regresi X1 Terhadap Y

\begin{tabular}{|l|l|l|l|l|l|}
\hline $\begin{array}{l}\text { Sumber } \\
\text { Varians }\end{array}$ & $\begin{array}{l}\text { Jumlah } \\
\text { Kuadrat }\end{array}$ & Df & $\begin{array}{l}\text { Rerata } \\
\text { Kuadrat }\end{array}$ & F $_{\text {hitung }}$ & Sig. \\
\hline $\begin{array}{l}1 \\
\begin{array}{l}\text { Regressi } \\
\text { on }\end{array}\end{array}$ & 6661.616 & 1 & 6661.616 & 71.256 & $.000^{\mathrm{a}}$ \\
$\begin{array}{l}\text { Residual } \\
\text { Total }\end{array}$ & 8039.975 & 86 & 93.488 & & \\
\hline
\end{tabular}

Sedangkan untuk menguji signifikansi koefisien parameter regresi antara variabel efektivitas kepemimpinan kepala sekolah $\left(\mathrm{X}_{1}\right)$ dengan variabel produktivitas kerja guru (Y) hipotesis yang digunakan $\mathrm{H}_{\mathrm{o}}$ yang menyebutkan bahwa variabel efektivitas kepemimpinan kepala sekolah tidak mempengaruhi variabel produktivitas kerja guru. Dan hipotesis alternatif $\left(\mathrm{H}_{1}\right)$ menyebutkan bahwa variabel efektivitas kepemimpinan kepala sekolah $\left(\mathrm{X}_{1}\right)$ mempengaruhi variabel produktivitas kerja guru(Y).

Tabel 22.
Analisis Uji Signifikansi Koefisien Parameter Regresi

\begin{tabular}{|c|c|c|c|c|c|}
\hline \multirow[b]{2}{*}{ Model } & \multicolumn{2}{|c|}{$\begin{array}{l}\text { Unstandardized } \\
\text { Coefficients }\end{array}$} & \multirow{2}{*}{$\begin{array}{l}\text { Standard } \\
\text { ized } \\
\text { Coeffici } \\
\text { ents } \\
\\
\text { Beta }\end{array}$} & \multirow[b]{2}{*}{$\mathrm{T}$} & \multirow[b]{2}{*}{ Sig. } \\
\hline & B & $\begin{array}{l}\text { Std. } \\
\text { Error }\end{array}$ & & & \\
\hline $1 \quad$ (Constant $)$ & 34.222 & 6.930 & & 4.938 & .000 \\
\hline Efektivitas & .608 & .072 & .673 & 8.441 & .000 \\
\hline
\end{tabular}

Berdasarkan hasil perhitungan di atas diperoleh nilai Sig. $=0,000$. Persyaratan hipotesis yang menyebutkan variabel efektivitas kepemimpinan kepala sekolah $\left(\mathrm{X}_{1}\right)$ mempengaruhi variabel produktivitas kerja guru (Y) pada model regresi tersebut nilai sig kurang dari nilai taraf signifikan sebesar 0,05 (5\%). Maka secara parsial variabel efektivitas kepemimpinan kepala sekolah $\left(\mathrm{X}_{1}\right)$ mempengaruhi variabel produktivitas kerja guru (Y). Dengan demikian dapat disimpulkan bahwa persamaan regresi . $\hat{Y}$ $=34,222 .+0,608 \mathrm{X}_{1}$ dikatakan pengaruhnya signifikan. Gambaran persamaan regresi linier variabel efektivitas kepemimpinan kepala sekolah $\left(\mathrm{X}_{1}\right)$ mempengaruhi variabel produktivitas kerja guru(Y) dapat dilihat pada gambar 1 di bawah ini

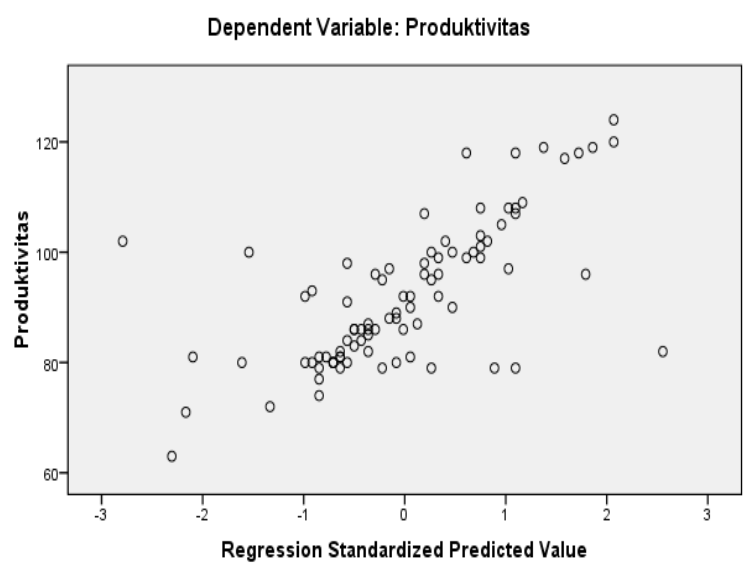

Hasil perhitungan kekuatan hubungan antara efektivitas kepemimpinan kepala sekolah $\left(\mathrm{X}_{1}\right)$ dengan produktivitas kerja guru SD Negeri di Kecamatan Tenggarong (Y) ditunjukan oleh nilai koofisien korelasi $\left(\mathrm{r}_{\mathrm{yx} 1}\right)$ sebesar 0,673 menunjukan hubungan yang kuat. Untuk 
menguji hubungan hipotesis yang menyebutkan terdapat hubungan yang positif antara variabel $\mathrm{X}_{1}$ dengan variabel $\mathrm{Y}$ diperlukan uji signifikansi koefisien korelasi yaitu jika sig $<$ taraf signifikansi $\alpha=0,05$. Berdasarkan hasil perhitungan menggunakan program SPSS versi 16.0 for windows nilai sig $=0,000$. Hal ini berarti bahwa koefisien korelasi antara efektivitas kepemimpinan kepala sekolah dengan produktivitas kerja guru SD Negeri Di Kecamatan Tenggarong adalah signifikan.

Hipotesis yang menyatakan bahwa terdapat hubungan yang positif antara efektivitas kepemimpinan kepala sekolah dengan produktivitas kerja guru SD Negeri di Kecamatan Tenggarong dapat diterima. Artinya makin tinggi nilai efektivitas kepemimpinan kepala sekolah maka semakin tinggi nilai produktivitas kerjanya. Hasil perhitungan uji signifikansi korelasi antara variabel efektivitas kepemimpinan kepala sekolah $\left(\mathrm{X}_{1}\right)$ dengan produktivitas kerja guru SD Negeri di Kecamatan Tenggarong $(\mathrm{Y})$ dapat dilihat pada tabel 23.

Tabel 23 .

Hasil Perhitungan Uji Koefisien Korelasi Variabel $\mathrm{X}_{1}$ dengan $\mathrm{Y}$

\begin{tabular}{|l|l|l|l|l|}
\hline $\begin{array}{l}\text { Kefis } \\
\text { ien } \\
\text { Korel } \\
\text { asi } \\
\left(\mathrm{r}_{\mathrm{y} \times 2)}\right)\end{array}$ & $\begin{array}{l}\text { Koefisi } \\
\text { en } \\
\text { Determi } \\
\text { nasi } \\
\left(\mathrm{r}_{\mathrm{yx} 2}{ }^{2}\right)\end{array}$ & $\begin{array}{l}\text { Nil } \\
\text { ai } \\
\text { Sig }\end{array}$ & $\begin{array}{l}\text { Nil } \\
\text { ai } \\
\alpha\end{array}$ & $\begin{array}{l}\text { Kesimp } \\
\text { ulan }\end{array}$ \\
0.673 & 0.453 & $\begin{array}{l}0,0 \\
00\end{array}$ & $\begin{array}{l}0,0 \\
5\end{array}$ & $\begin{array}{l}\text { Signifik } \\
\text { an }\end{array}$ \\
\hline
\end{tabular}

Pada tabel di atas tampak bahwa koofisien korelasi $\left(\mathrm{r}_{\mathrm{yx} 2}\right)$ sebesar 0,673 menunjukan hubungan yang sangat kuat. Nilai koefisien determinasi antara iklim organisasi dengan variabel produktivitas kerja guru adalah $\mathrm{r}_{\mathrm{yx} 2}{ }^{2}=$ 0,453 , hal ini berarti bahwa $45,3 \%$ varians produktivitas kerja guru dapat dipengaruhi oleh variabel efektivitas kepemimpinan kepala sekolah dan sisanya dipengaruhi oleh variabel lain yang tidak berhasil diteliti.

\section{Hubungan antara Iklim Organisasi $\left(X_{2}\right)$ dengan Produktivitas Kerja Guru (Y)}

$\mathrm{H}_{\mathrm{o}}: \rho_{\mathrm{y} 2}=0$
$\mathrm{H}_{1}: \rho_{\mathrm{y} 2}>0$

Hipotesis yang dikemukakan untuk hipotesis alternatif $\left(\mathrm{H}_{1}\right)$ adalah "terdapat hubungan yang positif dan signifikan antara iklim organisasi dengan produktivitas kerja guru SD Negeri di Kecamatan Tenggarong". Sedangkan untuk hipotesis nol $\left(\mathrm{H}_{0}\right)$ dirumuskan, "tidak terdapat hubungan yang positif dan signifikan antara iklim organisasi dengan produktivitas kerja guru SD Negeri di Kecamatan Tenggarong". Untuk keperluan pengujian digunakan analisis regresi sederhana dan korelasi sederhana.

Hasil perhitungan analisis regresi uji signifikansi persamaan garis regresi sederhana dan linieritas antara variabel iklim organisasi $\left(\mathrm{X}_{2}\right)$ dengan Produktivitas kerja guru(Y) menghasilkan arah regresi (b) sebesar 1,011 dan konstanta (a) sebesar 6,780. Dengan demikian bentuk hubungan antara kedua variabel tersebut dapat digambarkan oleh persamaan $\hat{Y}=6,780+$ $1,011 \mathrm{X}_{2}$.

Selanjutnya untuk mengetahui derajat keberartian persamaan regresi dilakukan dengan uji F. Persyaratan hipotesis apabila Sig $<\alpha=$ 0,05 . Berdasarkan hasil perhitungan uji signifikansi regresi seperti tampak pada tabel 24 diperoleh nilai $\operatorname{Sig}=0,000$. Apabila nilai $\operatorname{sig} \mathrm{di}$ bandingkan dengan nilai $\alpha$, maka $0,000<0,05$. Hal ini menunjukan bahwa hubungan antara variabel iklim organisasi $\left(\mathrm{X}_{2}\right)$ dengan variabel produktivitas kerja guru (Y) adalah positif dan sangat signifikan. Selengkapnya hasil perhitungan uji signifikansi regresi antara variabel iklim organisasi $\left(\mathrm{X}_{2}\right)$ dengan variabel produktivitas kerja guru (Y) dapat dilihat pada tabel di bawah ini :

Tabel 24.

Analisis Varians Uji Signifikansi Persamaan Regresi $\mathrm{X}_{2}$ Terhadap Y

\begin{tabular}{|c|c|c|c|c|c|}
\hline Model & $\begin{array}{l}\text { Sum of } \\
\text { Squares }\end{array}$ & Df & $\begin{array}{l}\text { Mean } \\
\text { Square }\end{array}$ & $\mathrm{F}$ & Sig. \\
\hline 1 Regression & 9286.812 & 1 & $\begin{array}{l}9286.81 \\
2\end{array}$ & $\begin{array}{l}147.49 \\
7\end{array}$ & $.000^{\mathrm{a}}$ \\
\hline Residual & 5414.779 & 86 & 62.963 & & \\
\hline Total & 14701.591 & 87 & & & \\
\hline \multicolumn{6}{|c|}{$\begin{array}{l}\text { a. Predictors: (Constant), } \\
\text { Iklim }\end{array}$} \\
\hline $\begin{array}{l}\text { b. Depend } \\
\text { Produktivitas }\end{array}$ & Var & riable & & & \\
\hline
\end{tabular}


Sedangkan untuk menguji signifikansi koefisien parameter regresi antara variabel iklim organisasi $\left(\mathrm{X}_{2}\right)$ dengan variabel produktivitas kerja guru (Y), hipotesis yang digunakan $\mathrm{H}_{\mathrm{o}}$ yang menyebutkan bahwa variabel iklim organisasi tidak mempengaruhi variabel produktivitas kerja guru. Dan hipotesis alternatif $\left(\mathrm{H}_{1}\right)$ menyebutkan bahwa variabel iklim organisasi $\left(\mathrm{X}_{2}\right)$ mempengaruhi variabel produktivitas kerja guru $(\mathrm{Y})$.

Tabel 25. Analisis Signifikansi Koefisien Parameter Regresi

\begin{tabular}{|c|c|c|c|c|c|}
\hline \multirow[b]{2}{*}{ Model } & \multicolumn{2}{|c|}{$\begin{array}{l}\text { Unstandardize } \\
\text { d Coefficients }\end{array}$} & \multirow{2}{*}{\begin{tabular}{|l}
$\begin{array}{l}\text { Standardize } \\
\text { d } \\
\text { Coefficients }\end{array}$ \\
Beta
\end{tabular}} & \multirow[b]{2}{*}{$\mathrm{t}$} & \multirow[b]{2}{*}{ Sig. } \\
\hline & B & $\begin{array}{l}\text { Std. } \\
\text { Error }\end{array}$ & & & \\
\hline $\begin{array}{ll}1 & \text { (Const } \\
& \text { ant) }\end{array}$ & 6.780 & 7.073 & & .959 & .340 \\
\hline Iklim & 1.011 & .083 & .795 & 12.145 & .000 \\
\hline
\end{tabular}

a. Dependent Variable:

Produktivitas

Berdasarkan hasil perhitungan di atas diperoleh nilai Sig. $=0,000$. Persyaratan hipotesis yang menyebutkan variabel iklim organisasi $\left(\mathrm{X}_{2}\right)$ mempengaruhi variabel produktivitas kerja guru(Y) pada model regresi tersebut nilai sig kurang dari nilai taraf signifikan sebesar 0,05 $(5 \%)$. Maka secara parsial variabel variabel iklim organisasi $\left(\mathrm{X}_{2}\right)$ mempengaruhi variabel produktivitas kerja guru(Y). Dengan demikian dapat disimpulkan bahwa persamaan regresi . $\hat{Y}$ $=6.780+1.011 \mathrm{X}_{2}$ dikatakan pengaruhnya sangat signifikan. Gambaran persamaan regresi linier variabel iklim organisasi $\left(\mathrm{X}_{2}\right)$ mempengaruhi variabel produktivitas kerja guru (Y) dapat dilihat pada gambar 12 di bawah ni

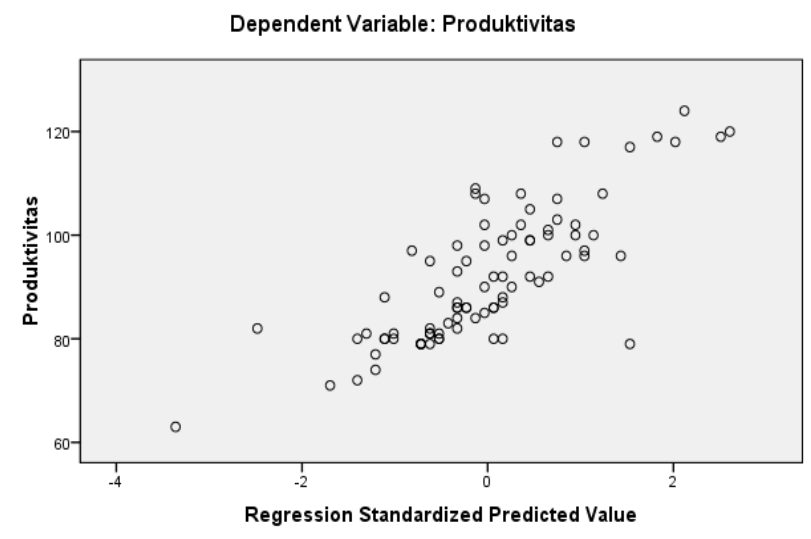

Hasil perhitungan kekuatan hubungan antara iklim organisasi $\left(\mathrm{X}_{2}\right)$ dengan produktivitas kerja guru SD Negeri di Kecamatan Tenggarong (Y) ditunjukan oleh nilai koofisien korelasi $\left(\mathrm{r}_{\mathrm{yx} 2}\right)$ sebesar 0,795 menunjukan hubungan yang sangat kuat. Untuk menguji hubungan hipotesis yang menyebutkan terdapat hubungan yang positif antara variabel $\mathrm{X}_{2}$ dengan variabel $\mathrm{Y}$ diperlukan uji signifikansi koefisien korelasi yaitu jika sig $<$ taraf signifikansi $\alpha=0,05$. Berdasarkan hasil perhitungan menggunakan program SPSS versi 16.0 for windows nilai sig $=$ 0,000 . Hal ini berarti bahwa koefisien korelasi antara iklim organisasi dengan produktivitas kerja guru SD Negeri di Kecamatan Tenggarong adalah sangat signifikan.

Hipotesis yang menyatakan bahwa terdapat hubungan yang positif antara iklim organisasi dengan produktivitas kerja guru SD Negeri di Kecamatan Tenggarong dapat diterima. Artinya makin tinggi nilai iklim organisasi maka semakin tinggi nilai produktivitas kerjanya. Hasil perhitungan uji signifikansi korelasi antara variabel iklim organisasi $\left(\mathrm{X}_{2}\right)$ dengan produktivitas kerja guru SD Negeri di Kecamatan Tenggarong (Y) dapat dilihat pada tabel 26.

Tabel 26 Hasil Perhitungan Uji Koefisien Korelasi Variabel $\mathrm{X}_{2}$ dengan $\mathrm{Y}$

\begin{tabular}{|l|l|l|l|l|}
\hline $\begin{array}{l}\text { Kefisien } \\
\text { Korelasi } \\
\left(\mathrm{r}_{\mathrm{y} \times 2)}\right)\end{array}$ & $\begin{array}{l}\text { Koefisien } \\
\text { Determinasi } \\
\left(\mathrm{r}_{\mathrm{yx} 2}\right)^{2}\end{array}$ & $\begin{array}{l}\text { Nilai } \\
\text { Sig }\end{array}$ & $\begin{array}{l}\text { Nilai } \\
\alpha\end{array}$ & Kesimpulan \\
\hline 0.795 & 0.632 & 0,000 & 0,05 & Signifikan \\
\hline \multicolumn{4}{|l|}{ Syarat signifikan sig $<\alpha$} \\
\hline
\end{tabular}

Pada tabel di atas tampak bahwa koofisien korelasi $\left(\mathrm{r}_{\mathrm{yx} 2}\right)$ sebesar 0,795 menunjukan hubungan yang sangat kuat. Nilai koefisien determinasi antara iklim organisasi dengan variabel produktivitas kerja guru adalah $\mathrm{r}_{\mathrm{yx} 2}{ }^{2}=$ 0,632 , hal ini berarti bahwa $63,2 \%$ varians produktivitas kerja guru dapat dipengaruhi oleh variabel iklim organisasi dan sisanya dipengaruhi oleh variabel lain yang tidak berhasil diteliti. 


\section{Hubungan Efektivitas Kepemimpinan Kepala Sekolah $\left(X_{1}\right)$ dan Iklim Organisasi $\left(\mathrm{X}_{2}\right)$ Secara Bersama-Sama dengan Variabel Produktivitas Kerja Guru (Y)}

Hipotesis yang dikemukakan untuk hipotesis alternatif $\left(\mathrm{H}_{1}\right)$ adalah "terdapat hubungan yang positif dan signifikan secara bersama-sama antara efektivitas kepemimpinan kepala sekolah dan iklim organisasi dengan produktivitas kerja guru SD Negeri di Kecamatan Tenggarong". Sedangkan untuk hipotesis nol $\left(\mathrm{H}_{0}\right)$ dirumuskan, "tidak terdapat hubungan yang positif dan signifikan secara bersama-sama antara efektivitas kepemimpinan kepala sekolah dan iklim organisasi dengan produktivitas kerja guru SD Negeri di Kecamatan Tenggarong”.

Hasil perhitungan analisis regresi uji signifikansi persamaan garis regresi sederhana dan linieritas secara bersama-sama antara variabel efektivitas kepemimpinan kepala sekolah $\left(\mathrm{X}_{1}\right)$ dan iklim organisasi $\left(\mathrm{X}_{2}\right)$ dengan produktivitas kerja guru(Y) menghasilkan arah regresi sebesar $0,232 \mathrm{X}_{1}$ dan $0,793 \mathrm{X}_{2}$ dan konstanta 3,090. Dengan demikian bentuk hubungan antara ketiga variabel tersebut dapat digambarkan oleh persamaan $\hat{\mathrm{Y}}=3,090+$ $0,232 X_{1}+0,793 X_{2}$.

Selanjutnya untuk mengetahui derajat keberartian persamaan regresi dilakukan dengan uji F. Persyaratan hipotesis apabila Sig $<\alpha=$ $0,05(5 \%)$. Berdasarkan hasil perhitungan uji signifikansi regresi seperti tampak pada tabel 4.14 diperoleh nilai $\mathrm{Sig}=0,000$. Apabila nilai sig di bandingkan dengan nilai $\alpha$, maka $0,000<$ 0,05 . Hal ini menunjukan bahwa hubungan secara bersama-sama antara variabel efektivitas kepemimpinan kepala sekolah $\left(\mathrm{X}_{1}\right)$ dan iklim organisasi $\left(\mathrm{X}_{2}\right)$ dengan variabel produktivitas kerja guru (Y) adalah positif dan sangat signifikan. Selengkapnya hasil perhitungan uji signifikansi dan nilai koefisien regreasi antara variabel efektivitas kepemimpinan kepala sekolah $\left(\mathrm{X}_{1}\right)$ dan iklim organisasi $\left(\mathrm{X}_{2}\right)$ dengan variabel produktivitas kerja guru (Y) dapat dilihat pada tabel di bawah ini.
Tabel 27.

Analisis Varians Uji Signifikansi Persamaan Regresi $\hat{\mathrm{Y}}=3,090+0,232 \mathrm{X}_{1}+0,793 \mathrm{X}_{2}$.

\begin{tabular}{|c|c|c|c|c|c|}
\hline Model & $\begin{array}{ll}\text { Sum } & \text { of } \\
\text { Squares }\end{array}$ & Df & $\begin{array}{l}\text { Mean } \\
\text { Square }\end{array}$ & $F$ & Sig. \\
\hline $\begin{array}{l}1 \text { Regressio } \\
\mathrm{n}\end{array}$ & 9827.402 & 2 & 4913.701 & 85.689 & $.000^{\mathrm{a}}$ \\
\hline Residual & 4874.189 & 85 & 57.343 & & \\
\hline Total & 14701.591 & 87 & & & \\
\hline \multicolumn{6}{|c|}{$\begin{array}{l}\text { a. Predictors: (Constant), } \\
\text { Iklim, Efektivitas }\end{array}$} \\
\hline \multicolumn{6}{|c|}{$\begin{array}{l}\text { b. Dependent Variable: } \\
\text { Produktivitas }\end{array}$} \\
\hline
\end{tabular}

Sedangkan untuk menguji signifikansi koefisien parameter regresi antara variabel efektivitas kepemimpinan kepala sekolah $\left(\mathrm{X}_{1}\right)$ dan iklim organisasi $\left(\mathrm{X}_{2}\right)$ dengan variabel produktivitas kerja guru (Y), hipotesis yang digunakan $\mathrm{H}_{\mathrm{o}}$ yang menyebutkan bahwa secara bersama-sama variabel efektivitas kepemimpinan kepala sekolah dan iklim organisasi tidak mempengaruhi variabel produktivitas kerja guru. Dan hipotesis alternatif $\left(\mathrm{H}_{1}\right)$ menyebutkan bahwa secara bersama-sama variabel efektivitas kepemimpinan kepala sekolah $\left(\mathrm{X}_{1}\right)$ dan iklim organisasi $\left(\mathrm{X}_{2}\right)$ mempengaruhi variabel produktivitas kerja guru $(\mathrm{Y})$

Berdasarkan hasil perhitungan diperoleh nilai Sig. $=0,000$. Persyaratan hipotesis yang menyebutkan secara bersama-sama variabel efektivitas kepemimpinan kepala sekolah $\left(\mathrm{X}_{1}\right)$ dan iklim organisasi $\left(\mathrm{X}_{2}\right)$ mempengaruhi variabel produktivitas kerja guru $(\mathrm{Y})$ pada model regresi tersebut nilai sig kurang dari nilai taraf signifikan sebesar 0,05 (5\%). Maka secara parsial variabel kepemimpinan kepela sekolah $\left(\mathrm{X}_{1}\right)$ dan iklim organisasi $\left(\mathrm{X}_{2}\right)$ mempengaruhi variabel produktivitas kerja guru (Y). Dengan demikian dapat disimpulkan bahwa persamaan regresi $\hat{Y}=3,090+0,232 X_{1}+0,793 X_{2}$. dikatakan pengaruhnya sangat signifikan.

Hasil perhitungan kekuatan hubungan secara bersama-sama antara variabel efektivitas kepemimpinan kepala sekolah $\left(\mathrm{X}_{1}\right)$ dan iklim organisasi $\left(\mathrm{X}_{2}\right)$ dengan produktivitas kerja guru SD Negeri di Kecamatan Tenggarong (Y). Untuk menguji hubungan hipotesis yang menyebutkan terdapat hubungan yang positif antara variabel $\mathrm{X}_{1}$ dan $\mathrm{X}_{2}$ dengan variabel $\mathrm{Y}$ 
diperlukan uji signifikansi koefisien korelasi yaitu jika sig $<$ taraf signifikansi $\alpha=0,05$. Berdasarkan hasil perhitungan menggunakan program SPSS versi 16.00 for windows nilai sig $=0,000$. Karena $0,000<0,05$, maka hal ini berarti bahwa koefisien korelasi secara bersamasama antara efektivitas kepemimpinan kepala sekolah dan iklim organisasi dengan produktivitas kerja guru SD Negeri di Kecamatan Tenggarong adalah sangat signifikan.

Hipotesis yang menyatakan bahwa terdapat hubungan yang positif antara efektivitas kepemimpinan kepala sekolah dan iklim organisasi dengan produktivitas kerja guru SD Negeri di Kecamatan Tenggarong dapat diterima. Artinya makin tinggi nilai efektivitas kepemimpinan kepala sekolah dan nilai iklim organisasi maka semakin tinggi nilai produktivitas kerjanya. Hasil perhitungan uji koefisien korelasi antara variabel efektivitas kepemimpinan kepala sekolah $\left(\mathrm{X}_{1}\right)$ dan iklim organisasi $\left(\mathrm{X}_{2}\right)$ dengan produktivitas kerja guru SD Negeri di Kecamatan Tenggarong (Y) dapat dilihat pada tabel 28 di bawah ini.

Tabel 28. Hasil Perhitungan Uji Koefisien Korelasi Variabel $\mathrm{X}_{1} \mathrm{X}_{2}$ dengan $\mathrm{Y}$

\begin{tabular}{|l|l|l|l|l|}
\hline $\begin{array}{l}\text { Kefisien } \\
\text { Korelasi } \\
\left(\mathrm{r}_{\mathrm{yx} 1 \times 2)}\right)\end{array}$ & $\begin{array}{l}\text { Koefisien } \\
\text { Determinasi } \\
\left(\mathrm{r}_{\left.\mathrm{yx} 1 \times 2^{2}\right)}\right)\end{array}$ & $\begin{array}{l}\text { Nilai } \\
\text { Sig }\end{array}$ & $\begin{array}{l}\text { Nilai } \\
\alpha\end{array}$ & Kesimpulan \\
\hline 0.818 & 0.668 & 0,000 & 0,05 & Signifikan \\
\hline \multicolumn{2}{|l|}{ Syarat signifikan sig < $<$} \\
\hline
\end{tabular}

Sumber: hasil penelitian

Nilai koefisien determinasi antara efektivitas kepemimpinan kepala sekolah dan iklim organisasi dengan variabel produktivitas kerja guru adalah $\mathrm{r}_{\mathrm{yx} 1}{ }^{2}=\mathbf{0 , 6 6 8}$., hal ini berarti bahwa $66,8 \%$ varians produktivitas kerja guru dapat dipengaruhi secara bersama-sama oleh efektivitas kepemimpinan kepala sekolah dan iklim organisasi , dan sisanya dipengaruhi oleh variabel lain yang tidak berhasil diteliti.

\section{Uji Korelasi Parsial}

Untuk menguji korelasi variabel-varabel efektivitas kepemimpinan kepala sekolah $\left(\mathrm{X}_{1}\right)$, iklim organisasi $\left(\mathrm{X}_{2}\right)$ dan produktivitas kerja guru SD Negeri di Kecamatan Tenggarong (Y), perhitungan menggunakan program SPSS versi
16.0 for windows. Hasil perhitungan uji signifikansi korelasi parsial dapat dilihat dalam tabel berikut ini:

Tabel 29. Ringkasan Hasil Perhitungan Korelasi Parsial

$$
\text { Variabel } \mathrm{X}_{1}, \mathrm{X}_{2} \text { dan } \mathrm{Y}
$$

\begin{tabular}{|c|c|c|c|c|}
\hline & & $\begin{array}{l}\text { Produktivi } \\
\text { tas }\end{array}$ & Efektivitas & Iklim \\
\hline $\begin{array}{l}\text { Produk } \\
\text { tivitas }\end{array}$ & $\begin{array}{l}\text { Pearson } \\
\text { Correlation } \\
\text { Sig. (2-tailed) } \\
\text { N }\end{array}$ & 88 & $\begin{array}{l}.673^{* *} \\
.000 \\
88\end{array}$ & $\begin{array}{l}.795^{* *} \\
.000 \\
88\end{array}$ \\
\hline $\begin{array}{l}\text { Efektiv } \\
\text { itas }\end{array}$ & $\begin{array}{l}\text { Pearson } \\
\text { Correlation } \\
\text { Sig. (2-tailed) } \\
\text { N }\end{array}$ & $\begin{array}{l}.673^{* *} \\
.000 \\
88\end{array}$ & $\begin{array}{l}1 \\
88\end{array}$ & $\begin{array}{l}.667^{* *} \\
.000 \\
88\end{array}$ \\
\hline Iklim & $\begin{array}{l}\text { Pearson } \\
\text { Correlation } \\
\text { Sig. (2-tailed) } \\
\text { N }\end{array}$ & $\begin{array}{l}.795^{* *} \\
.000 \\
88\end{array}$ & $\begin{array}{l}.667^{* *} \\
.000 \\
88\end{array}$ & $\mid \begin{array}{l}1 \\
88\end{array}$ \\
\hline
\end{tabular}

Sumber Hasil Penelitian

Berdasarkan hasil perhitungan seperti pada tabel di atas diperoleh nilai $r_{\mathrm{yx}}=0,673$ atau sebesar $67,3 \%$, hal ini menunjukan hubungan parsial yang sangat kuat antara $X_{1}$ dengan $Y$. Nilai sig = 0,000 digunakan taraf signifikansi $\alpha=0,05$ ini berarti menunjukan terdapat hubungan positif antara variabel efektivitas kepemimpinan kepala sekolah $\left(\mathrm{X}_{1}\right)$ dengan produktivitas kerja guru $\mathrm{SD}$ Negeri di Kecamatan Tenggarong(Y). Untuk variabel iklim organisasi dengan produktivitas kerja guru, berdasarkan hasil perhitungan seperti pada tabel di atas diperoleh nilai $\mathrm{r}_{\mathrm{yx} 2}=0,795$ atau sebesar 79,5\%, hal ini menunjukan hubungan parsial yang sangat kuat antara $\mathrm{X}_{2}$ dengan $\mathrm{Y}$ karena nilainya. Nilai sig $=0,000$ digunakan taraf signifikansi $\alpha=0,05$ ini berarti menunjukan terdapat hubungan positif antara variabel iklim organisasi $\left(\mathrm{X}_{2}\right)$ dengan produktivitas kerja guru SD Negeri di Kecamatan Tenggarong(Y).

Dan selanjutnya untuk variabel efektivitas kepemimpinan kepala sekolah dan iklim organisasi, berdasarkan hasil perhitungan seperti pada tabel di atas diperoleh nilai $\mathrm{r}_{\mathrm{x} 1 \times 2}=$ 0,667 atau sebesar $66,7 \%$, hal ini menunjukan hubungan parsial yang sangat kuat antara $X_{1}$ 
dengan $\mathrm{X}_{2}$. Nilai sig $=0,000$ digunakan taraf signifikansi $\alpha=0,05$ ini berarti menunjukan terdapat hubungan positif antara variabel efektivitas kepemimpinan kepala sekolah $\left(\mathrm{X}_{1}\right)$ dengan iklim organisasi SD Negeri di Kecamatan Tenggarong $\left(\mathrm{X}_{2}\right)$.

\section{E. Pembahasan Hasil Penelitian}

Berdasarkan hasil analisis data di atas, maka diperoleh hasil penelitian yang telah diuji berdasarkan hipotesis yang ada. Dari ketiga variabel yang diuji memiliki korelasi yang positif dan signifikan. Berikut ini pembahasan hubungan masing - masing variabel bebas terhadap variabel terikat.

\section{Hubungan Efektivitas Kepemimpinan Kepala Sekolah dengan Produktivitas Kerja Guru}

Hasil uji hipotesis menunjukkan bahwa terdapat hubungan yang positif antara efektivitas kepemimpinan kepala sekolah dengan produktivitas kerja guru. Maka semakin tinggi variable efektivitas kepemimpinan kepala sekolah, cenderung akan semakin tinggi pula produktivitas kerja guru tersebut. Sebaliknya, semakin rendah nilai variabel efektivitas kepemimpinan kepala sekolah, cenderung semakin rendah pula produktivitas kerja guru tersebut.

Efektivitas kepemimpinan kepala sekolah dalam rangka meningkatkan produktivitas kerja guru jelas sangat berpengaruh. Efektivitas kepemimpinan kepala sekolah memiliki konstribusi yang sangat kuat terhadap produktivitas kerja guru.

Secara terperinci kecenderungan umum responden pada variable efektivitas kepemimpinan kepala sekolah adalah sebagai berikut:

a. Perilaku pemimpin yang berorientasi terhadap tugas

Berdasarkan rata-rata perhitungan skor kecenderungan umum responden,ditemukan skor rata-rata sebesar 3,51. Artinya bahwa menurut penilaian para guru, kepala sekolah di SDN Negeri Kecamatan Tenggarong tingkat kecenderungan berorientasi terhadap tugasnya sangat tinggi.

b. Perilaku pemimpin yang berorientasi terhadap hubungan orang

Berdasarkan rata-rata perhitungan skor kecenderungan umum responden,ditemukan skor rata-rata sebesar 3,30. Artinya bahwa menurut penilaian para guru, kepala sekolah di SD Negeri Kecamatan Tenggarong tingkat kecenderungan berorientasi terhadap hubungan tinggi.

Berdasarkan penelitian yang relevan oleh Suparmadi tentang hubungan supervisi kepala sekolah dan motivasi kerja dengan produktivitas kerja guru sekolah dasar negeri di Kota Bontang. Dari hasil penelitan tersebut menunjukkan hubungan yang signifikan antara supervisi kepala sekolah dan produktivitas kerja guru. Hasil penelitian tersebut juga menyebutkan bahwa kepemimpinan kepala sekolah yang efektif adalah salah satu faktor yang mempengaruhi produktivitas kerja guru.

Penelitian tersebut didukung oleh Sutarto (2001:83) yang mengatakan bahwa kepemimpinan yang efektif memiliki ciri-ciri salah satunya mementingkan produksi yang tinggi.

Berdasarkan teori di atas dapat disimpulkan bahwa efektivitas kepemimpinan kepala sekolah adalah salah satu faktor yang diindikasikan sebagai faktor penentu produktivitas kerja guru. Bukti kebenaran ilmiah teori tersebut diperkuat oleh penelitian yang telah dilakukan peneliti di SD Negeri Kecamatan Tenggarong.

\section{Hubungan Iklim Organisasi dengan Produktivitas Kerja Guru}

Uji korelasi antara iklim organisasi dengan produktivitas kerja guru menunjukkan bahwa memiliki hubungan yang positif dan signifikan. Maka semakin tinggi nilai iklim organisasi semakin tinggi pula produktivitas kerja guru tersebut.

Dari hasil analisis tersebut membuktikan hipotesis penelitian pertama yang menduga ada hubungan antara iklim organisasi dengan produktivitas kerja guru SD Negeri di Kecamatan Tenggarong. Setelah didapatkan hasil perhitungan kecenderungan umum responden pada variabel iklim organisasi, ditemukan skor rata-rata sebesar 3,14. Jika dibandingkan dengan tabel kriteria di atas, maka iklim organisasi di SD Negeri Kecamatan Tenggarong secara keseluruhan berada pada kriteria baik atau kondusif bagi proses belajar mengajar. Sehingga berpengaruh signifikan terhadap produktivitas kerja guru. Secara 
terperinci kecenderungan umum responden pada variabel iklim organisasi adalah sebagai berikut:

a. Mutu Kepemimpinan

Berdasarkan rata-rata perhitungan skor kecenderungan umum responden,ditemukan skor rata-rata sebesar 3,50. Artinya bahwa mutu kepemimpinan kepala sekolah di SD Negeri Kecamatan Tenggarong sudah baik. Hal ini dikuatkan oleh Keith Davis dan Jhon W. Newstrom (1996:152) mengemukakan bahwa kepemimpinan adalah proses mendorong dan membantu orang lain untuk bekerja dengan antusias mencapai tujuan. Faktor kepemimpinan sangat berpengaruh terhadap iklim organisasi yang terbentuk karena sangat menentukan struktur organisasi, kebijakan serta praktek manajemen, dimana poin-poin tersebut merupakan unsur yang sangat menetukan suatu iklim organisasi (steer, 1985:145)

b. Motivasi kerja

Berdasarkan rata-rata perhitungan skor kecenderungan umum responden,ditemukan skor rata-rata sebesar 3,73. Artinya bahwa motivasi kerja guru SD Negeri di Kecamatan Tenggarong sudah sangat baik.

Hal ini sesuai dengan ungkapan Dirjen Dikti (Buku IIC, 1983:45), yang menyebutkan bahwa, "Iklim organisasi sangat mempengaruhi motivasi dan produktivitas para anggotanya untuk berpartisipasi, ada pula iklim yang justru memadamkan motivasi untuk berprestasi”.

c. Komunikasi dan interaksi

Berdasarkan rata-rata perhitungan skor kecenderungan umum responden,ditemukan skor rata-rata sebesar 3,88. Artinya bahwa Komunikasi dan interaksi sesama guru dan komunikasi dan interaksi guru dengan pimpinan di SD Negeri Kecamatan Tenggarong sudah sangat baik.

Menurut Steohen P Robbin (2009:311) komunikasi merupakan penyampaian dan pemahaman suatu maksud. Sejalan dengan pendapat ini seperti dalam pengertian organisasi yang dikemukakan oleh Hoy dan Miskel (dalam Nurdin, 2005:76) bahwa suatu iklim timbul melalui dari para bawahan dan anggota dan pertukaran perasaan diantara mereka. Begitu juga yang dikemukakan Davis dan Newstrom (1996:22), bahwa organisasi dapat terbentuk oleh sejumlah unsur, salah satunya komunikasi vertical-horizontal yang menjadi salah satu unsur yang dapat membentuk iklim organisasi yang menyenangkan. d. Pengambilan keputusan

Berdasarkan rata-rata perhitungan skor kecenderungan umum responden,ditemukan skor rata-rata sebesar 3,65. Artinya bahwa proses pengambilan dan penetapan keputusan di SD Negeri Kecamatan Tenggarong sudah baik. Terick dan Nancy Da Silva (dalam A. Nurdin. 2005:71) mengemukakan bahwa bila dalam suatu organisasi semua pengambilan keputusan dilakukan oleh satu orang yang berada dipucuk pimpinan, iklim organisasi tersebut adalah iklim kerja dengan tanggung jawab rendah. Hal ini berarti proses pengambilan keputusan turut menentukan iklim organisasi yang terbentuk. Pengambilan keputusan merupakan tindakan memilih berbagai alternative untuk mencapai tujuan atas sasaran tertentu

Dari Hasil penelitian dan pengujian hipotesis hubungan antara iklim organisasi dengan produktivitas kerja guru memberikan makna bahwa indikator iklim organisasi yang meliputi mutu kepemimpinan, komunikasi dan interkasi antar rekan kerja dan pimpinan, pembuatan keputusan, serta keamanan dan kenyamanan kerja yang dirasakan oleh guru terbukti mampu memberikan kontribusi yang signifikan terhadap produktivitas kerja guru SD Negeri di Kecamatan Tenggarong.

\section{Hubungan Efektivitas kepemimpinan kepala sekolah dan Iklim organisasi secara bersama-sama dengan Produktivitas Kerja Guru SDN di Kecamatan Tenggarong.}

Berdasarkan hasil penelitian di lapangan menunjukkan bahwa pengaruh efektivitas kepemimpinan kepala sekolah dan iklim organisasi secara simultan terhadap produktivitas kerja guru adalah sebesar $66,8 \%$. Adapun sisanya sebesar $(100 \%$ - 66,8 \%) yakni $33,2 \%$ dipengaruhi oleh variabel yang lain. Adapun persamaan regresi berganda yang diperoleh dengan menggunakan metode kuadrat terkecil ( least squares criterion ) adalah:

$\hat{Y}=3,090+0,232 X_{1}+0,793 X_{2}$

Dari persamaan tersebut tanda positif menunjukkan hubungan yang searah, artinya jika variabel efektivitas kepemimpinan kepala sekolah (X1) dan variabel iklim organisasi (X2) dapat ditingkatkan sebesar satu level, maka merunut kepada persamaan regresi di atas diperoleh: $\{\hat{Y}=3,090+0,232(1)+0,793(1)=$ 27,895 , sehingga dapat diprediksi bahwa 
variabel produktivitas kerja guru (Y) akan meningkat sebesar 4,115.

Fakta perhitungan di atas menunjukkan bahwa efektivitas kepemimpinan kepala sekolah dan iklim organisasi termasuk kepada faktor-faktor yang mempengaruhi tingkat produktivitas kerja guru. Hasil penelitian penulis di SD Negeri Kecamatan Tenggarong telah memperkuat teori keterkaitan kepemimpinan kepala sekolah dan iklim sekolah terhadap produktivitas kerja yang telah diutarakan (Gilmore,1974:6). Sesuai dengan penelitian tentang produktivitas kerja guru seperti yang dilakukan Donnelly, Gibson dan Ivancevich (1981:178), Made Pidarta (1988: 173) (E. Mulyasa, 2002:93); Robert Sutermeister, 1976:5, Renses Likert (Keith Davis dan Jhon W. Newstrom, 1996:24) Merujuk kepada teori tersebut, faktor kepemimpinan kepala sekolah dan iklim organisasi merupakan salah satu faktor yang banyak diindikasikan sebagai faktor penentu produktivitas kerja guru.

Bukti kebenaran ilmiah teori ini telah diperkuat oleh penelitian yang dilakukan penulis di SD Negeri Kecamatan Tenggrong

\section{KESIMPULAN}

Berdasarkan pembahasan diatas penulis dapat menarik kesimpulan bahwa :

1. Hubungan antara variable efektivitas kepemimpinan kepala sekolah $\left(\mathrm{X}_{1}\right)$ dengan variabel produktivitas kerja guru SDN Kecamatan Tenggarong (Y) positif dan signifikan.Hubungan (korelasi) positif pada tingkat keeratan yang kuat dan signifikan antara efektivitas kepemimpinan kepala sekolah dengan produktivitas kerja guru yaitu sebesar 0,673. Kontribusi efektivitas kepemimpinan kepala sekolah terhadap variabel produktivitas kerja guru adalah 0,453 yang dapat diinterpretasikan bahwa sebesar $45,3 \%$ varian produktivitas kerja guru dapat dipengaruhi oleh variabel efektivitas kepemimpinan kepala sekolah dan sisanya dipengaruhi variabel lain yang tidak diteliti dalam penelitian ini.

2. Hubungan (korelasi) variabel iklim organisasi $\left(\mathrm{X}_{2}\right)$ dengan variabel produktivitas kerja guru SDN di Kecamatan Tenggarong (Y) yang positif dan pada tingkat keeratan hubungan yang kuat dan sangat signifikan. Nilai korelasi antara iklim organisasi dengan produktivitas kerja guru yaitu sebesar 0,795 . Kontribusi iklim organisasi terhadap variabel produktivitas kerja guru adalah 0,632 yang dapat diinterpretasikan bahwa sebesar 63,2\% varian produktivitas kerja guru dipengaruhi oleh variabel iklim organisasi dan sisanya dipengaruhi variabel lain yang tidak diteliti dalam penelitian ini.

3. Terdapat hubungan yang positif dan signifikan antara variabel efektivitas kepemimpinan kepala sekolah $\left(\mathrm{X}_{1}\right)$ dan iklim organisasi $\left(\mathrm{X}_{2}\right)$ secara bersama-sama dengan produktivitas kerja guru SDN Kecamatan Tenggarong ( $\mathrm{Y}$ ) pada tingkat keeratan yang kuat. Nilai korelasi antara efektivitas kepemimpinan kepala sekolah dan iklim organisasi dengan produktivitas kerja guru yaitu sebesar 0,818 . Kontribusi iklim organisasi terhadap variabel produktivitas kerja guru adalah 0,668. yang dapat diinterpretasikan bahwa sebesar $66,8 \%$. varian produktivitas kerja guru dipengaruhi oleh variabel dua variabel efektivitas kepemimpinan kepala sekolah dan iklim organisasi serta sisanya dipengaruhi variabel lain yang tidak diteliti dalam penelitian ini.

\section{DAFTAR PUSTAKA}

Abd. Rahman Abor. (1994). Kepemimpinan Bagi Perbaikan dan Peningkatan Pengajar. Jogyakarta : Nur Cahaya.

Ahmad Tohardi. (2002). Pemahaman Praktis Manajemen Sumber Daya Manusia, Bandung : Mandar Maju.

Aksara. 2001

Andrew F. Sikula. (1976). Personal Administration and Human Resources Management. Canada : John Willey \& Son Inc.

Apple. (1982). Canadian Journal of Education, New York: Article Picture.

Arikunto, S. (2003). Dasar-dasar Eevaluasi Pendidikan. Jakarta: Bumi Aksara.

Charles R. Milton. (1976). Human Behavior in Organizators : Three Lvels of Behavior. New Jersey : Prentice Hall Inc. 
Coral A.O'Connor. (2002). Kepemimpinan Yang Sukses. Jakarta : Kesaint Balanc.

Cushway dan Lodge. (1999). Perilaku dan Desain Organisasi. Jakarta : Elex Media Komputindo.

E. Mulyasa. (2002). Manajemen Berbasis Sekolah. Bandung : Rosda Karya.

Ermaya Suradinata. (1979). Psikologi Kepegawaian. Bandung : Ramadan.

Ghozali, Imam, (2000). Aplikasi Analisis Multivariate dengan Program SPSS, Universitas Diponegoro, Yogyakarta.

Gilmore J.V, (1974). Productive Personality. Go. San Francisco: Albion Publisher.

Hasibuan H. Melayu , Manajemen Sumber Daya Manusia. Bumi

Herrsey, Paul dan Blanchard, K. H. (1998). Management of Organization Behavior, New York : Englewood Cliffs.

Hoy, Wayne K. \& Miskel, Cecil G. (2001). Education Administration: Theory, Research, and Practice $\left(6^{\text {th }}\right.$ ed., international edition). Singapure: $\mathrm{Mc}$ Graw-Hill Co.

Husaini, Usman. (2009). Manajemen, Teori dan Praktik dan Riset Pendidikan. Bumi Aksara. Jakarta: PT Elex Media Komputindo.

James A.Stoner. (1992). Management. New York : Prentice Hall Inc.

James H. Donnely Jr. (1998). Organisasi dan Manajemen : Perilaku, Struktur, Proses. Jakarta : Gramedia Pustaka Umum.

Kartini Kartono. (1992). Pemimpin. Jakarta : Rajawali.

Ken Balanchard Agus Dharma. (1996). Manajemen Prilaku Organisasi. Jakarta : Erlangga.
Lukman Ali. (1995). Kamus Besar Bahasa Indonesia. Jakarta : Perum Balai Pustaka.

M. Ngalim Purwanto. (1997). Administrasi dan Supervisi Pendidikan. Bandung : Remaja Rosda Karya.

Miftah Toha. (1995). Kepemimpinan dalam Manajemen. Jakarta :Raja Grafindo Persada.

Muchdarsyah Sinungan. (2000). Produktivitas Apa dan Bagaimana. Jakarta : Bumi Aksara.

Mulyasa, E. 2008. Standar Kompetensi dan sertifikasi Guru. Bandung: Remaja Rosdakarya.

Munday Robert. (1982). Leadeship Substitutes. NASSP : Journal Instructional.

Richard M. Steers. (1980). Efectivitas Organisasi:Kaidah Perilaku. Jakarta : Erlangga.

Riduwan (2009). Metode dan Teknik Menyusun Proposal Penelitian. Bandung: Alfabeta.

Riduwan. (2006). Skala Pengukuran variablevariable Penelitian. Bandung: CV. Alfabeta.

Robert N Lussier. (1996). Human Relation in Organization : A skill Bulding Approach. Chicago : Mc. Graw Hill Companies.

Robert Sutermeister. (1976). People and Productivity, Megraw Hill Company.

Romli Ardi. (2002). Hand out Kepemimpinan Pendidikan. Jakarta : PPS UHAMKA.

Rossow. (1990). Leadership-in-Education. English : Journal Instructional.

Salusu. (1996). Pengambilan Keputusan Strategik untuk Organisasi Publik dan Organisasi Nonprofit. Jakarta : Gramedia Widiasarana Indonesia.

Sedarmanti.2001. Sumber Daya Manusiadan Produktivitas Kerja. Bandung: Mandar Maju. 
Sondang P. Siagian, Organisasi, Kepemimpinan dan Perilaku Administrasi. Jakarta : Gunung Agung

Stepen Robbins. (1996). Prilaku Organisasi. Jakarta : Raja Grapindo Persada.

Sukarna. (1989). Kepemimpinan dalam Administrasi. Bandung : Mandar Maju.

Suparlan. 1997. Menjadi Guru Efektif. Yogyakarta: Hikayat Publishing

Sutarto. (2001). Dasar-dasar Kepemimpinan Administrasi, Yogyakarta: Gajah Mada University Press.

Terjemahan oleh Dimas Samudra Rum dan Soesanto Boediono. 1992.

Timpe, A.D. 1989. Seri Manajemen Sumber Daya Manusia: Produktivitas. 